DOI: https://doi.org/10.46630/phm.12.2020.43

Милица М. Алексић ${ }^{1}$

Универзитет у Нишу

Педагошки факултет у Врању
Оригинални научни рад УДК 821.163.41.09-93 Ђурђев Д. П. Примљен: 3. 3. 2020.

\title{
ИНТЕРТЕКСТУАЛНОСТ ЗБИРКЕ ПЕСАМА ПОПА Д. ЂУРЂЕВА ИЗВОЋАЧ БЕСНИХ ГЛИСТА
}

У раду ће бити анализирана интертекстуалност између песама из збирке Попа Д. Ђурђева Извођач бесних глиста и народне и неких других текстова ауторске књижевности, са освртом и на везу између ове Ђурђевљеве збирке песама и некњижевних типова дискурса какви су научни дискурс, телевизија и филм. Оваква усмереност метатекста на прототекст чини Ђурђевљеву поезију двогласном у бахтиновском смислу. Најчешћи облици двогласности речи у његовом тексту јесу стилизација и пародија, које доводе до хуморног или сатиричног ефекта, док се међу интертекстуалним поступцима издвајају цитат, алузија и парафраза. У раду ће бити указано и на повезаност између вербалног поигравања и хумора и нонсенса као доминантних елемената поезије за децу Попа Д. Ђурђева.

Кључне речи: Поп Д. Ђурђев, интертекстуалност, поезија за децу, двогласност речи, игра

Савремени српски књижевник Поп Д. Ђурђев (1953) заузима значајно место у историји српске књижевности за децу. Заједно са песницима Дејаном Алексићем и Владимиром Андрићем, он крајем XX и почетком XXI века наставља радовићевску линију нонсенсне поезије, зачету у књижевном делу Љубивоја Ршумовића седамдесетих година XX века (LJUŠTANOVIĆ 2012: 153-154). У Поговору збирке песама Блудилник: поетски практикум за усмерењаке Ђурђев је објаснио свој однос према књижевности за децу и књижевности уопште: он своја дела не пише примарно их намењујући деци, већ их деца касније препознају и прихватају као своја. У Ђурђевљевим делима не може се прецизно одредити граница између онога намењеног деци и онога намењеног одраслима, јер се „данас брже расте. Деци књиге окраћају, као панталоне“ (ĐURĐEV 1988: 71). Зато Ђурђев уважава личност детета као да је оно већ одрастао човек, обавештен и о ономе што му је још увек забрањено, те као такав слободан, јер „слобода - људска, дакле и дечја - почиње за-

\footnotetext{
${ }^{1}$ milica.aleksic.06@gmail.com
} 
виривањем у забрањено“ (DANOJLIĆ 2004: 95). Завиривање у забрањено јесте певање о еротским темама као нека врста песничког хибриса, али је то и дијалог са другим текстовима и медијима као важно обележје поезије за децу Попа Д. Ђурђева. Сви ови поступци чине Ђурђева „вишеструким песничким изгредником и прекршитељем, песником који прекорачује преко већине традиционалних граница у поезији за децу...“ (LJUŠTANOVIĆ 2002: 167)

Поднаслов: „Књига коју је захватила елементална непогода“ имплицитно најављује поетику збирке песама Извођач бесних глиста (2002) - то је књига настала као резултат песникове вербалне игре, игре коју песник именује као „елементалну“ уместо „елементарне“ непогоде и којој је услед промене само једног гласа промењен смисао. Исти је случај и са насловом првог поглавља: Fabula rasa. Игра је основни елемент Ђурђевљеве поезије за децу, и то не игра у смислу мимезиса дечјег живота, већ игра речима. Парономазија као вид вербалног поигравања једна је од најчешћих стилских фигура у Ђурђевљевој збирци Извођач бесних глиста, на коју он указује насловом трећег поглавља, Бла бла око стабла. У наслову збирке песник себе именује као извођача бесних глиста, односно као некога ко, попут детета, изводи бесне глисте, тј. чини разне несташлуке и каламбуре. Да је природа језика и стила једно од кључних питања Ђурђевљеве поезије песник објашњава у пролошкој песми ове збирке, Дегустацији, у којој позива читаоце на дегустацију речи, односно на читање.

Песме из ове збирке остварују богате интертекстуалне ${ }^{2}$ везе са народном и другим текстовима ауторске књижевности, али и са научним и другим видовима дискурса. Интертекстуални поступци заступљени у збирци песама Попа Д. Ђурђева јесу: а) цитат - уношење читавих стихова из једне народне или уметничке песме, б) алузија - наслућивање присуства неког другог текста и реминисценција на њега и в) парафраза - казивање нечег познатог другим речима, али тако да изворни смисао остане очуван. Они чине реч Ђурђевљеве поезије двогласном у бахтиновском смислу: глас у песми имплицира присуство неког пређашњег гласа. Најчешћи видови двогласности у Ђурђевљевим песмама јесу

\footnotetext{
${ }^{2}$ Интертекстуалност је термин који у науку о књижевности уводи Јулија Кристева 1966. године, инспирисана Бахтиновом теоријом о двогласности речи и анализама анаграма од стране Фердинанда де Сосира. Интертекстуалност се може дефинисати као скуп односа између текстова, као и између текста и вантекстовне стварности. Један текст увек је у дијалогу са другим, усмерен је на неки други текст, а ова идеја инспирисана је Бахтиновим ставом да реч никада није монолошка и увек је упућена некоме. Међу осталим теоретичарима значајним за развитак појма интертекстуалности, осим Кристеве и Бахтина, ваља поменути и Мајкла Рифатера, Жерара Женета, Џонатана Калера, Хенрика Маркјевича, Харолда Блума, Хермана Мајера.
} 
стилизација и пародија, које имају хуморни, односно сатирични ефекат. Песник користи „туђу реч за своје циљеве и на тај начин што ће унети нову смисаону усмереност у реч која већ има и која чува своју сопствену усмереност. При томе се таква реч, по императиву, мора осећати као туђа. У једној речи налазе се две смисаоне усмерености, два гласа“" (BAHTIN 1967: 261). Ђурђев и визуелно наглашава присуство туђих речи у свом тексту - оне су најчешће исписане болдираним и искошеним словима, чиме се скреће пажња читалаца на њих. Скретање пажње на прототекст додатно је постигнуто тзв. периграфијом, истицањем у рубним деловима текста (наслову, код Ђурђева ређе у поднаслову и мотоу). Функција таквог, алузивног цитатно-парафразног наслова је „најпре, коментаторска и антиципацијска: читаоцу наговештава тему текста или поглавља, упозорава на изабрани значењски аспект, указује на контраст или аналогију - семантичку, симболну, стилску, структурну, фабулативну или функционалну - између новог дела и цитираног предлошка“ (JUVAN 2013: 30).

Уношење цитата из једног прототекста у метатекст на композиционо-мотивском плану може довести до његовог проширења поступком амплификације. Један од најбољих примера за то јесте Ђурђевљева песма $O$ зецу који се начисто препородио, у којој је опеван несташлук дечака који је у игри поцепао свог плишаног зеку, да би дечакова мајка на крају песме нанету штету поправила крпљењем играчке. Читав овај догађај развијен је из стиха позајмљеног из шаљиве народне песме Ага Асан-ага и усмереност на ту myђy реч наглашена је болдирањем и подвлачењем:

„Иде ловац/ а основац/ па кад виде на нишану/ звер плишану/ погоди је између два скока/ у кољено међу оба ока// - Нека те нека -/ залелека зека/ а кад стаде паде/ сред душека мека/ Чу се дрека“ (ĐURĐEV 2002: 37).

Плишани зека је персонификован и његов је бол хиперболисан јер је заправо дечак тај који бурно реагује када схвати шта се десило. Захваљујући дечаковој мајци, плишани зека на крају песме је „начисто препорођен“. Повреда ове играчке „у кољено међу оба ока“, дакле, апсурдна је, баш као и повреда Асан-аге у шаљивој народној песми:

„Зеље бере ага Асан-ага/ У Мостару насред Сарајева;/ гледало га влаше испод Беча, / На Бијоград пушку наслонило:/ На зло га је мјесто погодило:/ Под кољено међу оба ока;/ Мртав паде ага Асан-ага,/ Мртав паде, здраво кући дође“ (KARADŽIĆ 2006: 175; курзив M.A).

Хипербола је присутна и у прототексту и у метатексту и њено ће коначно разобличење довести до хуморног ефекта. Овакво преузимање цитата из народне песме представља стилизацију, која сада „нагони туђу предметну замисао (уметничко-предметну) да служи њеним циљевима, то јест њеним новим замислима“ (BAHTIN 1967: 261). 
Ђурђевљева песма Прва бразда јесте пародија ${ }^{3}$ и једног текста народне и једног текста ауторске књижевности. Њен наслов алудира на истоветни наслов познате Глишићеве приповетке (GLIŠIĆ 1963: 477-484), да би се читалац у тексту сусрео са цитатом из народне песме Opaње Марка Краљевића (KARADŽIĆ 2006: 334), коју Душан Ђурђев пародира. Уместо Шарца, Марко Краљевић јаше рагу, која се жали на терет већи него што физички може да поднесе:

„Нек иду бестрага/ три товара блага -/ рече рага/ Таман да ме неко/ џага одострага/ откуд мени тол'ка снага/ липсаћу до кућног прага/ Иако се занемарује/ - Ум царује.../ послушај умове:/ Море Марко не ори друмове// Посла Марко рагу к врагу:/ - Ја сам ратар/ а не златар/ кад одем у атар/ ма коме је тамо раго/ још камење драго// Па када се газда сазда/ Прва бразда/ оста да се памти вазда““(ĐURĐEV 2002: 16).

Типски број три као број товара блага појављује се на почетку, а не на крају песме, какав је случај са прототекстом, у коме Марко Краљевић три товара блага на крају песме односи мајци као знак победе над Турцима. Уместо као награда, благо је у метатексту приказано као баласт, који рага физички није у стању да понесе. То њено нејуначко држање изненађује читаоца, чији хоризонт очекивања сада бива померен. У народној традицији, коњ Шарац верни је пријатељ Марка Краљевића и помаже му у борби са Турцима. Рага из Ђурђевљеве песме, насупрот томе, као слабић ниже једну за другом: псовку, део народне пословице („Ум царује, снага кладе ваља“) и цитат из народне песме о Марку Краљевићу, што доводи до вербалне комике. Највећи јунак српске народне епике узвраћа раги псовком и себе назива ратаром, чиме се пародира прототекст. Марко Краљевић више није велики епски јунак са верним коњем Шарцем, него обичан ратар са ислуженом рагом.

Песма Чича Томина кобила такође се пародијски односи према народној поезији о Марку Краљевићу, јер је у њој Шарац представљен као лечени алкохоличар. Шарац се, међутим, заљубљује у чича Томину кобилу и сада се она одаје алкохолу. Иако је о коњу променио мишљење набоље, чича Тома сада има неприлика са кобилом:

„Једино се плаши/ за судбину кобиљу/ одала се флаши/ у приличном обиљу/ па не лези враже/ када прекардаши/ уме да му каже:/ - Дај матори сјаши!“” (ĐURĐEV 2002: 18)

Песник се овде поиграо са жаргонском фразом „сјахати (некоме) с врата“, створивши ситуацију у којој је кобила персонификована, па је поменута

\footnotetext{
${ }^{3}$ Пародија (грч. para - поред, код, уз; оidia - песма, спев) „означава двоумљење: с једне стране, пародија наступа као додатак, пратиља предлошка, а с друге стране као његова супротност“ (JUVAN 2013: 37). Предмет преузет из прототекста у пародији се приказује нижим стилом, тако да тај несклад изазива подсмех.
} 
фраза и буквално реализована. То је уједно и један имплицитни вид борбе потлачених против оних на вишем друштвеном положају. Јунак песме, чича Тома, у другој строфи добија епитет „неверни“, што је алузија на библијску ${ }^{4}$ причу о неверном Томи. И са̂м наслов представља вербално поигравање у виду анаграмског премештања редоследа слогова: колиба - кобила, јер песма Чича Томина кобила успоставља интертекстуалне везе и са романом Харијете Бичер Стоу Чича Томина колиба (BIČER STOU 1990). Роман америчке ауторке представља причу о робовима и дехуманизацији друштва, о класним разликама, па и приказивање чича Томе и кобиле у Ђурђевљевој песми има симболичку функцију.

Песма Још нам Али Баба фали успоставља интертекстуални однос са Причама из хиљаду једне ноћи (вид. у: VINAVER 2002), збирком песама Љубивоја Ршумовића Још нам само але фале (RŠUMOVIĆ 1988) и народном причом Деда и репа (у: LOVRIĆ 1989). Наслов песме алузија је на Ршумовићеву збирку песама за децу, што је мотивисано сличношћу заједничке именице ала и властитог имена јунака из Прича из хиљаду једне ноћи Али Бабе. Други део његовог имена, Баба, песнику оставља простор за даље вербално поигравање, па главни јунак ове песме постаје управо баба, и то она која ће, за разлику од народне приче, уместо репе сама бити ишчупана, али из полиције (у песми је употребљен жаргонизам марица). Бабу је напало четрдесет разбојника, међутим, долази до неочекиваног, комичног обрта, па баба сама успева да савлада сву четрдесеторицу. Хипербола је овде у тесној повезаности са демистификацијом, поступком карактеристичним и за Ршумовићеву збирку песама Jош нам само але фале. Разбојници, као и але, бивају разобличени, а њихова снага знатно умањена, чиме је песник одагнао страх код малих читалаца. Ипак, несвакидашње храбра баба због физичког обрачуна са разбојницима доспева у полицију. Завршетак песме, у којем она бива „ишчупана из марице“, представља пародију мотива из народне приче Деда и реna: „Било је повуци-потегни/ и ишчупаше бабу“" (ĐURĐEV 2002: 10).

Пародирана је и бајка Браће Грим Црвенкапа (вид. GRIM 2009a) у Ђурђевљевој песми Нова теорија о настанку врста, у којој је мотив вађења Црвенкапе и њене баке из стомака злог вука обрађен у контексту савременог доба и високих достигнућа у области медицине:

„Са свога имена/ да спере љагу/ после онога у шипрагу/ своју вучицу драгу/ одвуче вук/ на ултразвук/ Завлада мук/ кад доца/ ловац Јоца/ поче да звоца:/ - Да ли сте ви у браку/ ил' ја то видим у стомаку/ Црвенкапу и

${ }^{4}$ Алузију на библијску причу представља и Ђурђевљева песма Нојева барка (вид. ĐURĐEV 2002: 42-43). Ноје из приче о потопу у овој песми постаје ној, обична „тркаћа живина“. Побожност и богоугодност Нојева благо су карикиране песниковим апострофирањем Бога: „(Боже мој)“ и „,(хвала Богу)“. Као такви, ови искази представљају коментаре. Ној је у бари тражио барку, па се поново успоставља вербална игра паронима: Ноје - ној, барка - бара. 
баку?// Да сте видели тај кез/ кад је направио царски рез/ и донео на свет, у неку руку/ заједно баку и унуку// Сви су се дивили/ изузимајући пар старих циника/ честитала му је цела/ гинеколошко-акушерска клиника// Само је несрећни отац/ почео да кука:/ - Не може наука и струка/ тек тако да се брука/ човек је постао од мајмуна/ а не од вука// Ипак је, у присуству звери/ признао за своје обе кћери/ а биле су задовољне и једна и друга кћерка/ јер им је отац - велика зверка“ (ĐURĐEV 2002: 33-34).

Ова песма представља реминисценцију и на бајку о Црвенкапи, али и на Дарвинову теорију о постанку врста и песму Драгана Лукића Ловаи Jou̧a (LUKIĆ 2018: 17). Поп Ђурђев узима за свог јунака познатог ловца из Лукићеве песме, али је притом ловац Јоца код Ђурђева тек споредни јунак, очишћен од реминисценције на прототекст, јер, према Бахтину, „Све што улази у дело мора да се потопи у Лету, да заборави свој ранији живот у туђим контекстима: у песничким контекстима језик може да памти само свој живот (овде су могућне и конкретне реминисиенције)“ (BAHTIN 1989: 53). Сличан је случај и са Ђурђевљевим песмама Биберче и Мачји кашаљ, које за прототекстове имају народну бајку Биберче (у: ĐURIĆ 1991: 223-226), односно бајку Шарла Пероа Мачак у чизмама (PERO 1969), али их од њих сасвим удаљавају нонсенс и хумор, као и природа позајмљених јунака. Мачка у песми Мачји кашаљ користи чизме да не би назебла јер у противном мора да се попне на дрво, да „седне у рашље и кашље“ (ĐURĐEV 2002: 48). И фразу „мачји кашаљ“, којом се примарно означава нешто безазлено и незнатно, песник је обрадио на хуморни начин. Он у радовићевском маниру рачуна на интелектуалност малих читалаца, остављајући им простор да сами процене да ли ће веровати у нонсенсну ситуацију опевану у песми.

Песма О Ивищи, Марици и злочестој старищчи на неочекиван начин обједињује јунаке бајки Браће Грим Ивица и Марищуа (GRIM 1988) и Пепељуга (GRIM 2009b), критички се разрачунавајући са жанром бајке, као што ће то учинити и у неким другим песмама у збирци Блудилник5:

„Другарица Марица/ иначе шипарица/ рече да та старица/ имала је прошлост бурну/ док је Иван/ киван/ не гурну/ у урну// Шта је могла друго/ а и живела си дуго/ Пепељуго“" (ĐURĐEV 2002: 29).

Осим са бајкама, поезија Попа Д. Ђурђева у дијалошком је односу и са кратким књижевним врстама, које су у песмама парафразиране или цитиране. Осим истоимене латинске изреке у наслову, Ђурђевљева песма Lupus in fabula за прототекст има и легенду о постанку Рима, али и дискурс о Вуку Стефановићу Караџићу. Животиња вук из ове латинске изреке у песми постаје Вук (Стефановић Караџић), а њему се при-

${ }^{5}$ У питању је песма Бајка коју сте већ чули: „Снежана је једна била/ и с њом седам имбецила““ (ĐURĐEV 1988: 50). 
дружује вучица, преузета из легенде о постанку Рима. Тиме њихов спој, уз придруживање Браће Грим на крају, прелази у нонсенс:

„Знаш ни нама вучицама/ не цветају руже друже/ бадава ми стручна спрема/ откад нема Ромула и Рема/ па зар због тог да свој бол/ утапам у алкохол// Он раздужи лулу рум и буре/ - Вреди због такве цуре -/ рече па вучицу/ ухвати за ручицу/ а она вука око струка/ и одоше у... Тршић/ па онда код његових у Беч/ затим код њених у Рим/ тако је било часна реч/ али не разумем шта с тим/ имају браћа Грим“ (ĐURĐEV 2002: 36).

Ова песма критички се опходи према чињеници да се Вук Стефановић Караџић са̂м школовао, будући да вук у песми признаје како је „,..] вук самоук/ зато нисам мого ничим/ много да се дичим/ давали ми окрајке од бајке/ е сада ћу шором шајке..." (ĐURĐEV 2002: 35) Песник се послужио и војвођанском ${ }^{6}$ изреком „Шором шајке, а Дунавом чезе“, чији је први део инкорпорао у свој текст визуелно га истичући. Сви ови елементи сврставају песму Lupus in fabula у тематски круг песама пародијског карактера.

У песми која обилује нонсенсом и хумором, љубавни живот жалосних врба, парафразиране су народна изрека: „Кад врба грожђем роди“ (KARADŽIĆ 1965: 134) и брзалица: „На врх брда врба мрда“ (VUJČIĆ 2008: 124):

„Дошла свадба тужни гости/ Боже ме опрости/ Као да је дан жалости// Господин је фин/ али врбов клин/ а његова лепша пола/ пуна бола/ сад једва да игде мрда/ са вр' брда// Он је чува/ од ветра што дува/ а и да се не догоди/ да на врби грожђе роди“ (ĐURĐEV 2002: 57, курзив M.A).

Песник се на овом месту још једном поиграо са народном традицијом и уобичајеним називом поменуте биљке - жалосна врба, те овакав њихов спој представља нонсенс. Персонификовано је и дрво у песми Добро дрво, за које друго дрво каже да је ударено мокром крпом, што представља парафразу народне изреке: „Ударен мокром чарапом“ (VUJČIĆ 2008: 207).

Осим кратких књижевних врста, у Ђурђевљевим песмама могу бити сакривена и имена неких других књижевника или наслови неких других песама. У фусноти песме На 20.000 миља од цุиља, која успоставља интертексту-

\footnotetext{
${ }^{6}$ Из војвођанске је средине и песма Шта ће мени коњи вранци (текст је доступан на линку: https://srbin.info/kultura/uz-narodnu-romansu-sta-ce-meni-konji-vranci-zelimo-vamprijatnu-noc/), чије је стихове Ђурђев унео у песму (Š)eppur si muove: „Шта ће мени тол'ки ланци/ Шта ће мени коњи вранци“ (ĐURĐEV 2002: 22).
}

${ }^{7}$ Фуснота представља паратекстуални коментар, који се одликује дигресивношћу и због тога је увек изван приче (MILOSAVLJEVIĆ MILIĆ 2006: 256). Паратекст и јесте и није део основног текста и такав његов амбивалентан положај опевао је и Бранко Миљковић (2003: 189) у својим стиховима: „Песма и наслов воде љубав/ Неко време, а затим/ 
алне везе са романом Жила Верна 20.000 миља под морем (VERN 1986), визуелно је истакнуто име овог француског књижевника: „... како би то извесни Жил верн/о описао“" (ĐURĐEV 2002: 13). Са именом писца Максима Горког Ђурђев се поиграо у песми Звека чини човека, где је искористио фонолошку блискост властитог имена Максим и именице максима: „после ту максиму приписаше Горком“ (ĐURĐEV 2002: 17). Поменути поступци спадају у домен стилизације, која има за циљ ефекат изненађења код читаоца.

Интертекстуалност Ђурђевљеве поезије успоставља се и непосредним цитирањем стихова из ауторске поезије. Такав је пример песме Професионално обољење, у којој је цитиран стих песме Ђуре Јакшића (1978: 70) Кроз поноћ...: „О лакше, лакше кроз густо грање“. Његово уношење у Ђурђевљев текст о шумару и шуми представља стилизацију као вид двогласности речи. Осим тога, песник се и вербално поиграва са паронимима секира - секирати се, јер их семантички доводи у везу са шумарем. Тако он на духовит начин завршава своју песму:

„О лакие, лакше кроз густо грање/ у дебелом 'ладу/ јер је секирање/ повреда на раду““ (ĐURĐEV 2002: 63).

Исту функцију има и Ђурђевљево цитирање стиха Велимира Рајића (1964: 185-186): „Проста ти била моја љубав жива“ у песми $O$ људима $u$ зверима. Поменути стих има потпуно другачије читање у једном и другом тексту. Код Рајића, он се понавља као рефрен песме На дан њеног венчања и тиме појачава осећање бола лирског субјекта због губитка вољене жене. У Ђурђевљевој песми, он звучи подсмешљиво, будући да га изговара крокодил, тобоже заљубљен у камилу:

„- Ма 'де била/ дуж Нила -/ рече La costa:/ - Проста ти била моја љубав жсива -/ и оде да плива/ Нилом/ рептил стилом/ кријући своју интиму/ y la costimu“ (ĐURĐEV 2002: 41).

Песник кокетира са популарном културом, па и крокодил и камила у његовом тексту добијају имена по најпознатијим брендовима са амблемом управо ових двеју животиња - La costa и Camel, а господин у последњој строфи песме јесте савремени потрошач, човек XXI века, коме су доступни најквалитетнији брендови, али човек дехуманизован и отуђен, који ради свог задовољства жртвује друга жива бића:

„Да ли је реч о срећи/ тешко је рећи/ и како је зверима међу људима/ тек господин сад Camel пуши/ a La costu носи на грудима/ и на души“ (ĐURĐEV 2002: 42).

Алузија је као интертекстуални поступак искоришћена у песми Партеногенеза, у којој је приказана камила која преокреће грбу на сто-

Презиру једно друго и свако пева за себе“. 
мак понашајући се као да је трудна, и то како би се одморила од уобичајеног јахања од стране бедуина и његовог сина. Аутор текста претпоставља читаочево познавање романа Виктора Игоа Богородичина ирква у Паризу (IGO 1985), прототекста из кога позајмљује књижевног јунака Квазимода, физичку наказу каква би настала и из фантомске трудноће персонификоване камиле. Интенција аутора чисто је стилистичке природе - камила која покушава да избегне своје обавезе и одмори се изазива хумор код читаоца.

Посебном тематском кругу припадају песме које су у дијалошком односу са научним дискурсом, медијима, ТВ серијама и филмом, или се пак тај дијалошки однос у појединим Ђурђевљевим песмама истовремено успоставља и са њима и са књижевним текстовима. Ту спадају: Ghost busters, Прохујало са вихором, Ко год воли нек изволи доли и Позоpuште у кући. Заједничка овим песмама јесте алузија, будући да се присуство прототекста у њима тек наслућује. Песма Ghost busters алудира на филм Kacnep из 1995. године, као и на источњачку причу о Аладину из Хиљаду и једне ноћи (вид. у: VINAVER 2002). Џин из Аладинове лампе близак је добром духу Касперу, а са̂м мотив духа песник хумористички доводи у везу са духовним правима због фонолошке сличности ових паронима. Мотив фантастичног бића у лампи у Ђурђевљевој песми обрађен је тако да се дух са „угроженим духовним правима“ нашао у плинској боци, у којој је био под притиском. На крају текста песник се поиграо и са познатом изреком: „У здравом телу - здрав дух“, коју сада преиначава у: „У здравом канистеру, здрав дух“ (ĐURĐEV 2002: 12). Песма Позориште у кући представља алузију на истоимену ТВ серију ${ }^{8}$, а песма Прохујало са вихором на чувени роман и филм ${ }^{9}$ са истим насловом. Не треба занемарити ни друге интертекстуалне везе песме Прохујало са вихором, пре свега са кратким књижевним формама - изрекама „Дотерати цара до дувара“ и „Познајем га као (слијепац) рђав новац“ (KARADŽIĆ 1965: 236), да би фуснота ове песме сакрила и један појам из области тениса (дупли пас), географски појам (планине Овчар и Каблар) и назив једне расе пса (Немачки овчар): „Немачки Овчар и Каблар - дупли пас“ (ĐURĐEV 2002: 25). Све то указује на

\footnotetext{
${ }^{8}$ Прва сезона телевизијске серије Позориште у кући премијерно је приказивана у периоду од октобра 1972. до априла 1973 , да би током 1974, 1975, 1981. и 1984. биле снимљене и емитоване још четири сезоне. Сценарио је написао Новак Новак, а серију режирао Дејан Баја Ћорковић. Више о овоме прочитати на линку: https://sr.wikipedia.org/srec/\%D0\%9F \%D0\%BE\%D0\%B7\%D0\%BE\%D1\%80\%D0\%B8\%D1\%88\%D1\%82\%D0\%B5_\%D1\%83_\%D0\% BA\%D1\%83\%D1\%9B\%D0\%B8. Године 2007. у режији Мирослава Лекића снимљен је и римејк ове популарне телевизијске серије.

${ }^{9}$ Америчка књижевница Маргарет Мичел године 1936. објавила је књигу Прохујало са вихором, по којој ће три године касније бити снимљен и филм у режији Виктора Флеминга.
} 
маестралну способност вербалне игре Попа Д. Ђурђева и неопходност читаочевог доброг познавања опште културе.

Песма (̌̌) eppur si muоve представља стилизацију дискурса о Галилеу Галилеју. Мотив игре и идеја о Галилејевом хелиоцентричном систему нашли су тачку пресецања када је у овом тексту дечаку упао кликер у блато. Једна сасвим обична ситуација из живота детета обогаћена је хумором и неочекиваним спојем са Галилеом и његовом чувеном изреком: „Ипак се окреће“ када блатњав кликер буде морао да сачека да се тротоaр осуши како би поново могао да се котрља. Наслов песме преведен је у фусноти: „(Ш)Ипак се окреће“ (ĐURĐEV 2002: 21), која представља цитирање као интертекстуални поступак. Овакав наслов представља духовит коментар-наслов о читавој причи текста, истовремено антиципирајући садржину песме и исказујући песников став о томе.

Песма Ко год воли нек изволи доли јесте алузија на прву клонирану овцу по имену Доли, на шта је, између осталог, указано у фусноти: „По клону се зуби не гледају“ (ĐURĐEV 2002: 47). Ауторов паратекстуални коментар јесте и парафраза народне изреке: „Поклону се у зубе не гледа“" (KARADŽIĆ 1965: 236) и алузија на клонирану овцу. У портрету ове црне овце, како је аутор још назива, јавља се низ нонсенсних и хуморних елемената: она је рођена у хороскопском знаку овна, носи само чисту рунску вуну, премазана је свим мастима, а, иако у глави има црну рупу, „сви опет у њу блеје““ (ĐURĐEV 2002: 47).

Збирка песама Попа Д. Ђурђева Извођач бесних глиста успоставља интертекстуалне односе са народном и другим текстовима ауторске књижевности, као и са некњижевним типовима дискурса попут филма, научног дискурса, телевизијских серија, појмова из опште културе. Интертекстуални поступци у њој јесу цитирање (песме $O$ људима и зверима, $O$ зеиу који се начисто препородио, Професионално обољење), алузија (Чича Томина кобила, Партеногенеза, Нојева барка, Прва бразда, Мачји кашаљ) и парафраза (љубавни живот жалосних врба, Добро дрво). Ђурђев пародира фолклорно наслеђе у својим песмама Прва бразда, Чича Томина кобила и Lupus in fabula. Осим пародије, дијалошку реч у његовој поезији представља и стилизација, која, за разлику од пародије, за циљ нема сатирични смех, већ онеобичавање постојећег, његово ново сагледавање и читање, као и хумор изазван ефектом изненађења. Све то чини поезију Душана Ђурђева неком врстом споне између прошлости и будућности. Његова постмодернистичка поезија узима за грађу мотиве и делове текстова које су оставили његови претходници, али их обрађује на потпуно нов и оригиналан начин, остављајући богато наслеђе и неким будућим генерацијама књижевника. 


\section{Цитирана литература}

BAHTIN 1989: BAHTIN, Mihail. O romanu. Preveo Aleksandar Badnjarević. Beograd: Nolit, 1989.

BAHTIN 1967: BAHTIN, Mihail. Problemi poetike Dostojevskog. Prevela Milica Nikolić. Beograd: Nolit, 1967.

DANOJLIĆ 2004: DANOJLIĆ, Milovan. Naivna pesma: ogledi i zapisi o dečjoj književnosti. Beograd: Zavod za udžbenike i nastavna sredstva, 2004. [orig.] Данојлић, Милован. Наивна песма: огледи и записи о дечјој књижевности. Београд: Завод за уџбенике и наставна средства, 2004.

JUVAN 2013: JUVAN, Marko. Intertekstualnost. Prevela Bojana Stojanović Pantović. Novi Sad: Akademska knjiga, 2013.

LJUŠTANOVIĆ 2012: LJUŠTANOVIĆ, Jovan. Književnost za decu u ogledalu kulture. Novi Sad: Zmajeve dečje igre, 2012. [orig.] Љуштановић, Јован. Кьижевност за деиу у огледалу културе. Нови Сад: Змајеве дечје игре, 2012.

MILOSAVLJEVIĆ MILIĆ 2006: MILOSAVLJEVIĆ MILIĆ, Snežana. Modeli komentara u srpskom romanu 19. veka. Niš: Filozofski fakultet - Prosveta, 2006: 255-268. [orig.] Милосављевић Милић, Снежана. Модели коментара у српском роману 19. века. Ниш: Филозофски факултет - Просвета, 2006: 255-268.

\section{Извори}

BIČER STOU 1990: BIČER STOU, Harijeta. Čiča Tomina koliba. Sarajevo: Svjetlost, 1990.

ĐURĐEV 1988: ĐURĐEV, Pop D. Bludilnik: poetski praktikum za usmerenjake. Beograd: „Vuk Karadžić, 1988. [orig.] ЂУРЂЕВ, Поп Д. Блудилник: nоетски практикум за усмерењаке. Београд: „Вук Караџић“, 1988.

ĐURĐEV 2002: ĐURĐEV, Pop D. Izvođač besnih glista: knjiga koju je zahvatila elementalna nepogoda. Zrenjanin: Gradska narodna biblioteka „Žarko Zrenjanin“, 2002. [orig.] ЂУРЂЕВ, Поп Д. Извођач бесних глиста: књига коју је захватила елементална непогода. Зрењанин: Градска народна библиотека „Жарко Зрењанин“, 2002.

ĐURIĆ 1991: „Biberče“. Antologija narodnih pripovedaka. Priredio Vojislav Đurić. Beograd: Srpska književna zadruga, 1991: 223-226. [orig.] „Биберче“. Антологија народних приповедака. Приредио Војислав Ђурић. Београд: Српска књижевна задруга, 1991: 223-226.

GLIŠIĆ 1963: GLIŠIĆ, Milovan. „Prva brazda“. Sabrana dela I. Beograd: Prosveta, 1963: 477-484. [orig.] Милован Ђ. ГЛИШИћ, „Прва бразда“. Сабрана дела I, Београд: Просвета, 1963: 477-484. 
GRIM 1988: BRAĆA GRIM. „Ivica i Marica“. Grimove bajke. Sarajevo: Svjetlost, 1988: 23-34. [orig.] БРАЋА ГРИМ. „Ивица и Марица“. Гримове бајке. Сарајево: Свјетлост, 1988: 23-34.

GRIM 2009a: BRAĆA GRIM. „Crvenkapa“. Izabrane bajke. Zemun: JRJ, 2009: 68-71. [orig.] БРАЋА ГРИМ. „Црвенкапа“. Изабране бајке. Земун: JPJ, 2009: 68-71.

GRIM 2009b: BRAĆA GRIM. „Pepeljuga“. Izabrane bajke. Zemun: JRJ, 2009: 100-108. [orig.] БРАЋА ГРИМ. „Пепељуга“. Изабране бајке. Земун: ЈРЈ, 2009: 100-108.

IGO 1985: IGO, Viktor. Bogorodičina crkva u Parizu. Izabrana dela, knj. 2. Beograd: Rad, 1985.

JAKŠIĆ 1978: JAKŠIĆ, Đura. „Kroz ponoć...“. Pesme. Sabrana dela Đure Jakšića, knj. 1. Beograd: Slovo ljubve, 1978: 70. [orig.] Ђура ЈАКШИЋ, „Кроз поноћ...“. Песме. Сабрана дела Буре Јакшића, књ. 1. Београд: Слово љубве, 1978: 70.

KARADŽIĆ 1965: Srpske narodne poslovice. Sabrana dela Vuka Karadžića, knj. 9. Priredio Miroslav Pantić. Beograd: Prosveta, 1965. [orig.] Српске народне пословице. Сабрана дела Вука Караџића, књ. 9. Приредио Мирослав Пантић. Београд: Просвета, 1965.

KARADŽIĆ 2006: KARADŽIĆ, Vuk. Srpske narodne pjesme. Beograd: Zavod za udžbenike i nastavna sredstva, 2006. [orig.] КАРАЏИЋ, Вук. Српске народне пјесме. Београд: Завод за уџбенике и наставна средства, 2006.

LOVRIĆ 1989: LOVRIĆ, Mate. (prir.). Deda i repa. Zagreb: Naša djeca, 1989. [orig.] ЛОВРИЋ, Мате. (прир.). Деда и репа. Загреб: Наша дјеца, 1989.

LUKIĆ 2018: LUKIĆ, Dragan. „Lovac Joca“. Svakoga dana. Beograd: Bookland, 2018: 17. [orig.] ЛУКИЋ, Драган. „Ловац Јоца“. Свакога дана. Београд: Bookland, 2018: 17.

MILJKOVIĆ 2003: MILJKOVIĆ, Branko „Pesma i naslov”. Pesme. Beograd: Narodna knjiga - Alfa, 2003: 189. [orig.] МИљКОВИЋ, Бранко. „Песма и наслов“. Песме. Београд: Народна књига - Алфа, 2003: 189.

PERO 1969: PERO, Šarl. Mačak u čizmama. Zagreb: Mladost, 1969. [orig.] ПEPO, Шарл. Мачак у чизмама. Загреб: Младост, 1969.

RAJIĆ 1964: RAJIĆ, Velimir. „Na dan njenog venčanja“. Antologija novije srpske lirike. Priredio Bogdan Popović. Beograd - Ljubljana: Savremena škola Mladinska knjiga, 1964: 185-186.

RŠUMOVIĆ 1988: RŠUMOVIĆ, Ljubivoje. Još nam samo ale fale. Čakovec: Zrinski, 1988.

VERN 1986: VERN, Žil. 20.000 milja pod morem. Sarajevo: Svjetlost, 1986.

VINAVER 2002: VINAVER, Stanislav. (prev.). Ali Baba i četrdeset razbojnika: priče iz 1001 noći. Beograd: Prosveta, 2002. [orig.] Винавер, Станислав. (прев.). Али Баба и четрдесет разбојника: приче из 1001 ноћи. Београд: Просвета, 2002. 
VUJČIĆ 2008: VUJČIĆ, Nikola. (prir.). Srpska narodna književnost za decu. Beograd: Zavod za udžbenike, 2008. [orig.] Вујчић, Никола. (прир.) Српска народна књижевност за децу. Београд: Завод за уџбенике, 2008.

„Šta će meni konji vranci“. <https://srbin.info/kultura/uz-narodnu-romansu-sta-cemeni-konji-vranci-zelimo-vam-prijatnu-noc/> 28.5.2020.

„Pozorište u kući“. $<$ https://sr.wikipedia.org/srec/\%D0\%9F\%D0\%BE\%D0\%B7\% D0\%BE $\%$ D1\%80\%D0\%B8\%D1\%88\%D1\%82\%D0\%B5 \%D1\%83 \%D0\% BA $\%$ D1\%83\%D1\%9B $\%$ D0\%B8 > 28.5.2020.

Milica Aleksić

\section{THE INTERTEXTUALITY OF POP D. ĐURĐEV'S COLLECTION OF POEMS IZVOĐAČ BESNIH GLISTA}

In this paper, the intertextuality between the pomes in Pop D. Đurđev's collection of poems Izvođač besnih glista and works of both oral and written literature, with emphasis on the connection between this collection of poems by Đurđev and non-literary discourses such as film, TV series, scientific discourse. The presence of such prototext and the orientation of the metatext towards it make Đurđev's poetry double-voiced in the Bakhtinian sense. The most common forms of double-voicedness of the words in his text are stylization and parody, leading to a humorous or satirical effect. The connection of humorous wordplay and nonsense as the dominant elements of Pop D. Đurđev's children's literature will also be presented in this paper.

Keywords: Pop D. Đurđev, intertextuality, children's literature, doublevoicedness of the words, wordplay 